\title{
Crohn's Disease Biologic Therapies Advances: A current review
}

\author{
Diana Serra $^{1 \#}$, Paulo Teixeira ${ }^{1,2 \#}$, Jorge Balteiro ${ }^{3}$, Rui Cruz ${ }^{3}$ and Fernando Mendes ${ }^{1,4,5,6 *}$ \\ ${ }^{1}$ Polytechnic Institute of Coimbra, ESTESC-Coimbra Health School, Department of Biomedical Laboratory Sciences, Coimbra, Portugal \\ ${ }^{2}$ Pathology Service, Coimbra Hospital and University Centre, Coimbra, Portugal \\ ${ }^{3}$ Polytechnic Institute of Coimbra, ESTESC-Coimbra Health School, Department of Pharmacy, Coimbra Portugal \\ ${ }^{4}$ Biophysics Unit-IBILI, Faculty of Medicine of University of Coimbra, Portugal \\ ${ }^{5}$ Center of Investigation in Environment, Genetics and Oncobiology (CIMAGO), Faculty of Medicine of University of Coimbra, Portugal \\ ${ }^{6}$ CNC.IBILI, Universidade de Coimbra, Portugal \\ \#Both authors contributed equally to the review
}

\begin{abstract}
Crohn's Disease (CD) is an intestinal chronic inflammatory disease included in the group of inflammatory bowel disease. It is associated with an inflammatory process and may affect any part of the gastrointestinal tract. The pathogenesis of CD has become better understood owing to advances in genetic and immunologic technology. Studies suggest that the origin of the inflammation may be due to an exacerbated response of the immune system. The elevated production of inflammatory cytokines, such as tumor necrosis factor-alpha, in CD patients were described. The new therapeutic with biological agents were developed for CD patients who not respond to conventional therapy. These novel biologics has been shown frequently to decrease the inflammatory activity in the gut, with the goal to achieve remission with mucosal healing. The Infliximab therapy is one of more used in these patients. However, there are many patients who do not respond or lose response. Who do not respond to these therapeutics have other biologic therapeutics such as Certolizumab Pegol, Natalizumab, Vedolizumab, Ustekinumab and Secukinumab. It is necessary to analyse the effectiveness and safety of these treatments to see which is most effective.
\end{abstract}

\section{Introduction}

The Inflammatory Bowel Disease (IBD) is a group of a chronic condition that includes Crohn's Disease (CD) and ulcerative colitis with unknown ethiology that affects the gastrointestinal tract [1,2]. $\mathrm{CD}$ is characterized by segmental granulomatous inflammation with periods of exacerbation and remission $[3,4]$.

In the bowel, the mucosa serves as a barrier between the host and Antigen (Ag) of the lumen. This mucosa balances the response to aggression and tolerates others $\mathrm{Ag}$ that are harmless [5]. The response of the Immune System (IS) occurs through a recognition of PathogenAssociated Molecular Patterns (PAMPs) by specific receptors [6]. One of the receptors, the Toll-Like Receptors (TLR), control intestinal epithelial homoeostasis and provides protection to the bowel to avoid tissue damage [7]. The interaction of PAMPs with TLR's activate a complex signalling cascade that results of several transcription factors and proinflammatory cytokine production. A dysregulated or aberrant TLR signaling in intestinal epithelial cells is an important pathogenic factor, leading to an increase tissue injury contributing to chronic intestinal inflammation [8].

Several studies identified a CD connection between the IS and the recognition of commensal bacteria receptors. It has been shown that IS exacerbated response leading to the imbalance between the proinflammatory and antiinflammatory cytokines produced by the mucosa in response to inflammation $[5,9,10]$. This lead to a disproportionate activation of $\mathrm{T}$ helper (Th) 1 cells and an overproduction of Interleukin (IL). An elevated level of several cytokines involved in inflammation, such as interferon gamma
(INF- $\gamma$ ), tumor necrosis factor-alpha (TNF- $\alpha$ ), IL-17, IL-23 and IL12 and an increase of lymphocyte infiltration the veins to the mucosa leads inflammatory lesions in the gut [3]. The increment of cytokines, such as IFN- $\gamma$, IL-12 and IL-23, leads the Th1 cells to an exaggerated immune response and their differentiation into Th17 that express IL17 , a cytokine with an important role in the development of intestinal mucosal damage [10]. One of the most potent proinflammatory mediators is the TNF- $a$ contributing to the destruction of the intestinal mucosa. This has contributed to chronically activated IS leading to chronic inflammation [9].

With these discoveries, several studies have been conducted to release new medical therapies against TNF- $\alpha$. Therapy with Infliximab (IFX), Adalimumab (ADA) or Certolizumab Pegol (CZP), are antibodies against TNF- $\alpha$, have demonstrated that it is effective in terms of induction and maintained responses [11-13]. Unfortunately, approximately $20-40 \%$ of CD patients do not respond to anti-TNF- $\alpha$ therapy and $40 \%$ of patients who initially respond lose response [14]. Those who do not respond to the first anti-TNF- $\alpha$ have lower response rates to the second or third with this kind of therapy. Several studies demonstrated that anti-TNF therapy is associated with side effects that include serious infections and malignancies [15]. New drug

Correspondence to: Fernando Mendes, Biomedical Laboratory Sciences Department, ESTeSC-Coimbra Health School, Rua 5 de Outubro - SM Bispo, 3046-854 Coimbra, Portugal, E-mail: fjmendes@estescoimbra.pt

Received: August 10, 2017; Accepted: September 11, 2017; Published: September 14, 2017 
options with alternative actions were created, including Natalizumab, Vedolizumab (VDZ), Ustekinumab, Secukinumab, among others [11].

The aim of this review is to analyze recent research about the action of IFX and to assess the effectiveness and safety of VDZ, CZP, Ustekinumab and Secukinumab for induction and maintenance treatment in adults with $\mathrm{CD}$.

\section{Material and methods}

This study consists of a review of the literature concerning biological therapies in CD.

The survey of information was carried out in online databases, mainly the PubMed database. The keywords in this research are: "Crohn's Disease", "Immune System", "Infliximab", "Ustekinumab", "Secukinumab", "Certolizumab Pegol” and "Vedolizumab".

An initial trial of papers of interest performed the relevance of the title and content of the abstract. Pre-selected articles were completely analysed and properly selected. The selection was based on the included criteria: papers in English, Scientific Article (SA), Review Articles (RA), Clinical Trials (CT) and original research papers available in free full text. Exclusion criteria were established as unavailability of selected papers in free full text and papers published before 2012. Full details of the search strategies used are provided in Figure 1. The summary of the articles included in the review is stipulated in Table 1.

Finally, all ethical questions have been fulfilled, and all the sources that provided the theoretical support have been properly referenced.

\section{Results}

\section{Ethiology}

The ethiology of CD maintains ununderstood but there have been several studies performed about the behaviour of IS in patients with CD. Immunological imbalance causes a chronic inflammation in consequence of a dysregulation of innate and adaptive immune response to commensal bacteria in the intestinal mucosa [1].

The activity of innate immune defences, like macrophages, has an important role in the protection and maintenance of the integrity of the intestinal mucosa. This is done by elimination of microbial agents, production cytokines and presentation antigen to other cells of the adaptive IS. These phagocytic cells, mainly the intermediate subset of macrophages, has shown low activity in the production of inflammatory cytokines in health intestinal in compared with CD patients [9].

The dysregulation of innate and adaptive IS usually is characterized by an increment of production of TNF- $\alpha$, IL-21, IFN- $\gamma$, IL-23 and IL-12. The IL-21, synthesized by Clusters Differentiation (CD) $4^{+}$Th cells, regulates $\mathrm{T}$ cell differentiation, induce receptors for other cytokines, drive the differentiation of B cells into memory, promote immunoglobulin secretion and enhances the activity of NK cells [10]. The IL-23 and IL-12 are responsible for the exacerbated Th1 response, the differentiation of Th1 cells into Th17 cells and the activation of NK cells [16]. With the appropriate stimuli of IL-23, the Th1 cells can be converted into Th17 cells. It has been demonstrated that Th17 cells and their cytokines (e.g. IL-17A, IL-21 and IL-23) are highly expressed in inflamed mucosa of CD patients [10]. Th1 and Th17 cells undergo apoptosis when galectin 9 (Gal-9), a physiological ligand, connects to T-cell immunoglobulin and mucin-domain-containing molecule 3 (TIM-3), expressed on the membrane of these cells. Regulatory T cells $\mathrm{CD} 4{ }^{+} \mathrm{CD} 25^{+}$(Tregs) are essential cells for the maintenance of mucosal tolerance regulated by forkhead box protein 3 (FOXP3) [1].

Another cytokine that has a crucial protective role in infectious disease and is involved in many autoimmune diseases is the IL-15. It is produced by activated monocytes, macrophages and dendritic cells. IL15 and IL-15Ra are related in the terms of promoting activity, survival and proliferation of immune cells, mainly memory $\mathrm{T}$ cells, Natural Killer cells, B cells, mast cells and phagocytic cells. Both IL-15 and IL$15 \mathrm{R} \alpha$ have an increased expression and production before stimulation in lamina propria of CD patients than Healthy Controls (HC) [17].

Angiogenesis in the gut has an important role in immune cells infiltrations that lead and enhances inflammatory cells infiltrations and histological lesions in CD patients. Many of the proinflammatory mediators expressing during inflammation, such as IL-1, TNF- $\alpha$ and growth factor alpha (TGF- $\alpha$ ), promote this pathological process in CD patients [18].

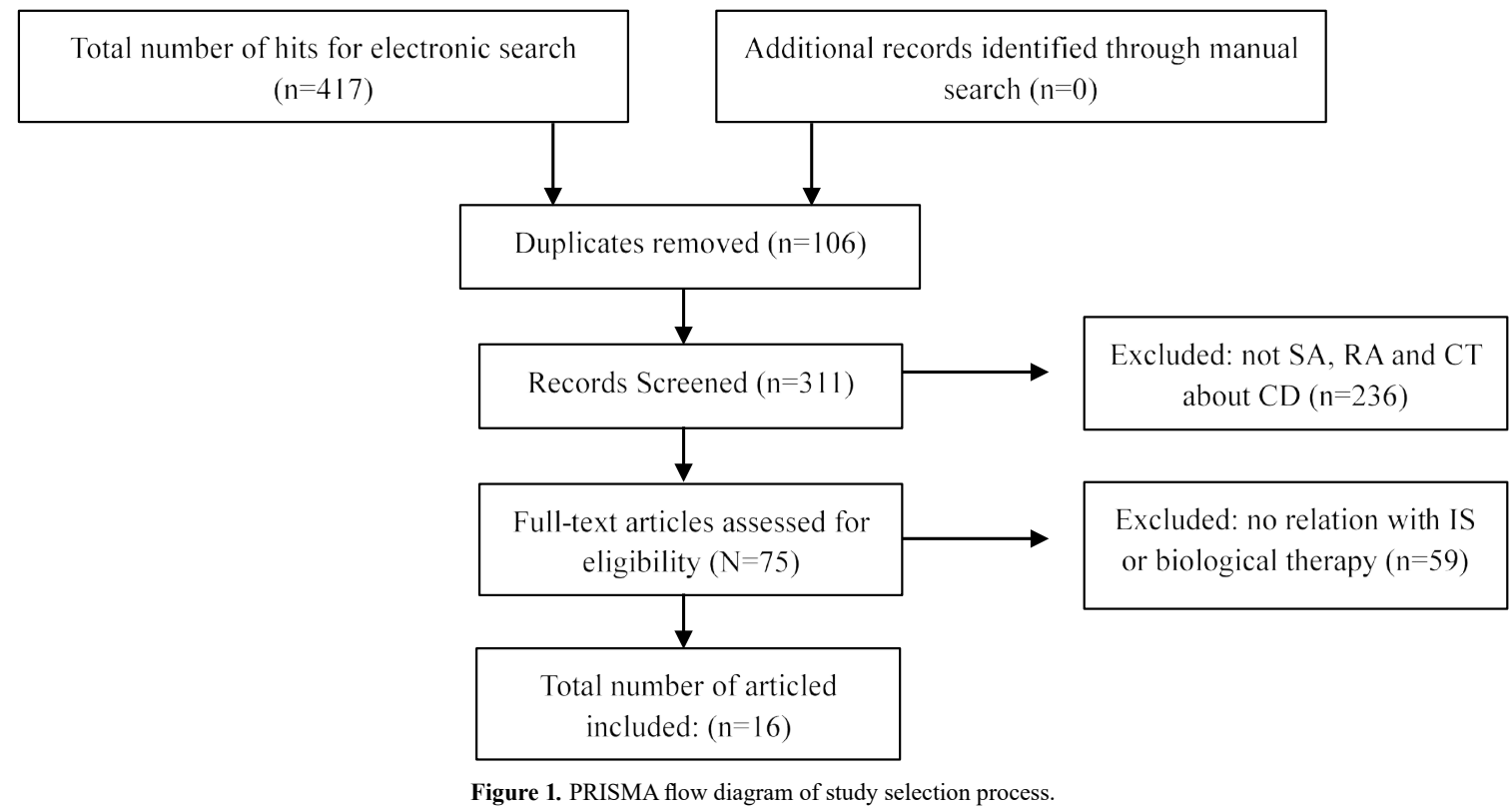


Table 1. Articles included in the literature review.

\begin{tabular}{|c|c|c|c|c|c|c|c|}
\hline REF & Author & Year & $\begin{array}{l}\text { Type of } \\
\text { Study }\end{array}$ & Population & Drug & Methods & Results \\
\hline [1] & $\begin{array}{l}\text { Kim MJ } \\
\text { et al. }\end{array}$ & 2015 & ES & $\begin{array}{l}20 \mathrm{PCD} \\
20 \mathrm{HC}\end{array}$ & IFX & $\begin{array}{l}\text { - The expression of TIM-3 mRNA in PBMC } \\
\text { and the level of TIM-3, HBD-2 and FOXP3 } \\
\text { mRNA in the CM was analysed by RT-PCR; } \\
\text { - The CD4, CD } 25 \text { and FOXP expression in } \\
\text { PB was made by FC and TNF- } \alpha \text { level was } \\
\text { determined in serum by ELISA. } \\
\text { - The expression of TIM-3 and FOXP3 was } \\
\text { detected by IHC in the CM; }\end{array}$ & $\begin{array}{l}\text { - The expression of mRNA TIM- } 3 \text { is highly expressed in } \\
\text { mucosa and lower in PBMC of PCD compared with HC. } \\
\text { After one year of IFX this value became inverse; } \\
\text { - The FOXP } 3^{+} \text {Treg demonstrated a negative correlation } \\
\text { between their frequency and CDAI; } \\
\text { - HBD-2 expression was increased in mucosa of PCD } \\
\text { compared to HC and decreased after IFX; } \\
\text { - The TNF- } \alpha \text { expression is increased in PCD in serum } \\
\text { compared to HC and decreased after IFX. }\end{array}$ \\
\hline [3] & $\begin{array}{l}\text { Wlodarczyk } \\
\text { et al. }\end{array}$ & 2014 & ES & $\begin{array}{l}30 \mathrm{PCD} \\
12 \mathrm{HC}\end{array}$ & $\begin{array}{l}\operatorname{IFX}(18) \\
\operatorname{ADA}(7) \\
\operatorname{CZP}(5)\end{array}$ & $\begin{array}{l}\text { - The levels of IL-17, IL-23 and IFN- } \gamma \text { was } \\
\text { quantified by ELISA; } \\
\text { - Qualified as skin lesions induced by anti- } \\
\text { TNF- } \alpha \text { therapy. }\end{array}$ & $\begin{array}{l}\text { - The level of IL-17A, IL- } 23 \text { and IFN- } \gamma \text { are increased in } \\
\text { serum of PCD compared to HC and decreased after IFX; } \\
\text { - In } 18 \text { of } 30 \text { adult PCD developed skin lesions during } \\
\text { therapy (12-IFX, 4-ADA -2 CZP); } \\
\text { - PCD with skin lesions had an increases of IL-17A and IL- } \\
23 \text { serum concentration. }\end{array}$ \\
\hline [9] & $\begin{array}{l}\text { Nazareth } \\
\text { et al. }\end{array}$ & 2014 & ES & $\begin{array}{l}69 \text { PCD-IFX } \\
22 \text { PCD-NIFX } \\
18 \text { HC }\end{array}$ & IFX & $\begin{array}{l}\text { - To evaluate infliximab-dependent effects on } \\
\text { monocyte subsets, they studied CD14 and } \\
\text { CD16 expression by PB monocytes before } \\
\text { and after different IFX administrations; } \\
\text { - Investigated the TNF secretion by } \\
\text { macrophages obtained from CD16 and } \\
\text { CD16 } 16^{-} \text {monocytes; } \\
\text { - Investigated the frequency of } \mathrm{TNF}^{+} \text {cells } \\
\text { among CD16 and CD16-. }\end{array}$ & $\begin{array}{l}\text { - Macrophages obtained from PCD-NIFX showed an } \\
\text { enhanced TNF bacterial-stimulation index in response to } \\
\text { infection by bacterial compared to HC and even more in } \\
\text { PCD-IFX; } \\
\text { - Macrophages from PCD-IFX showed enhanced IL-10 } \\
\text { secretion compared to PCD-NIFX; } \\
\text { - CD16 monocytes were more frequent in the PB of PCD } \\
\text { than in HC and increased with the addition of IFX. } \\
\text { The CD16 cells decreased along treatment and were more } \\
\text { expressed in HC. }\end{array}$ \\
\hline$[10]$ & Liu C et al. & 2013 & ES & $26 \mathrm{PCD}$ & IFX & $\begin{array}{l}\text { - The clinical response and remission were } \\
\text { evaluated by CDAI, endoscopic findings, } \\
\text { CRP and ESR; } \\
\text { - The mRNA IL-21, IL-17A, TNF- } \alpha \text { and } \\
\text { IFN- } \gamma \text { expression in biopsies was made } \\
\text { using PCR; } \\
\text { - The expression of IL- } 21 \text { and IL-17A } \\
\text { positive cells in mucosa was analysed by } \\
\text { IHC; } \\
\text { - To analyse cytokines production CD4 } \\
\text { cells were isolated and cultivated with the } \\
\text { addiction of IFX. }\end{array}$ & $\begin{array}{l}\text { - There was an improvement of SES-CD and a decreased of } \\
\text { CDAI, ESR and CRP after IFX; } \\
\text { - IFX demonstrated to down-regulate IL- } 21, \mathrm{TNF}-\alpha \text {, IFN- } \gamma \\
\text { and IL-17A mRNA expression in mucosa; } \\
\text { - The expression of IL- } 21^{+} \text {cells and IL- } 17^{+} \text {cells decreased } \\
\text { after IFX; } \\
\text { - IFX could supress the differentiation of naïve CD4 } 4^{+} \text {T cells } \\
\text { into Th17. }\end{array}$ \\
\hline [11] & $\begin{array}{l}\text { Cote- } \\
\text { Daigneault J } \\
\text { et al. }\end{array}$ & 2015 & $\mathrm{R}$ & NA & NA & $\begin{array}{l}\text { - Review the current state of biologic } \\
\text { therapies. }\end{array}$ & $\begin{array}{l}\text { - Studies about IFX, ADA, CZP, NTZ, VDZ and USTK } \\
\text { demonstrated that these therapies lead to induction and } \\
\text { maintenance CD; }\end{array}$ \\
\hline [12] & $\begin{array}{l}\text { Mc Lean } \\
\text { et al. }\end{array}$ & 2016 & $\mathrm{R}$ & NA & NA & $\begin{array}{l}\text { - It was made a review the current state of } \\
\text { anti-integrin therapy. }\end{array}$ & $\begin{array}{l}\text { Anti-integrin therapy, mainly VDZ, is effective for the } \\
\text { induction and maintenance of response and remission in PCD. }\end{array}$ \\
\hline [13] & $\begin{array}{l}\text { Bazola } \mathrm{F} \\
\text { et al. }\end{array}$ & 2012 & ES & 59 PCD & SCK & $\begin{array}{l}\text { - It was evaluated the efficacy and safety } \\
\text { in PCD that were randomly assigned to } \\
\text { receive SCK or placebo; }\end{array}$ & $\begin{array}{l}\text { - The reduction of CDAI in the placebo group was greater } \\
\text { then in the SCK group. These group had a greater } \\
\text { percentage of adverse events; } \\
\text { - The SCK was ineffective in this trial. }\end{array}$ \\
\hline [14] & Wils P et al. & 2016 & ES & $122 \mathrm{PCD}$ & USTK & $\begin{array}{l}\text { - All patients received at least } 1 \text { subcutaneous } \\
\text { injection of USTK with a follow-up of at } \\
\text { least } 3 \text { months and all patient's files were } \\
\text { reviewed; } \\
\text { - To determine safety, all adverse events were } \\
\text { recorded. }\end{array}$ & $\begin{array}{l}\text { - After } 3 \text { months, } 65 \% \text { ( } 58 \text { of } 122 \text { ) of patients had a clinical } \\
\text { benefit; } \\
\text { - In the patients with clinical benefit, } 95 \% \text { decreased CRP } \\
\text { levels being that } 41 \% \text { of these had normalized values; } \\
\text { - In } 22 \text { patients with endoscopic evaluation available, the } \\
\text { mucosal healing has been reached in } 9 \% \text { and endoscopic } \\
\text { response in } 77 \% \text {; } \\
\text { - An adverse event was developed in } 16 \% \text { of patients. }\end{array}$ \\
\hline [15] & Shelton et al. & 2015 & ES & 107 PCD & VDZ & $\begin{array}{l}\text { - All patients received VDZ at weeks } 0,2 \text {, } \\
6 \text { and } 14 \text { with data collected at each visit } \\
\text { with evaluation of the HBI for CD and CRP. }\end{array}$ & $\begin{array}{l}\text { - In } 42 \text { PCD with data available in week } 6 \text { and } 88 \text { in week } 14 \\
\text { the percentage who achieved clinical response and clinical } \\
\text { remission were } 59.5 \% \text { and } 35.7 \% \text {, and } 48.9 \% \text { and } 23.9 \% \text {, } \\
\text { respectively. } \\
\text { - An adverse event was seen in } 10.5 \% \text { of patients. }\end{array}$ \\
\hline [17] & $\begin{array}{l}\text { Perrier } C \\
\text { et al. }\end{array}$ & 2013 & ES & 65 PCD & IFX & $\begin{array}{l}\text { - For mRNA expression levels of IL-15R } \alpha \\
\text { and IL-15 in mucosa was used qRT-PCR; } \\
\text { - The expression of mRNA sIL-15R } \alpha \text { and IL- } \\
15 \text { in serum was made by ELISA and IL- } \\
15 \alpha^{+} \text {expression in biopsies by IHC; } \\
\text { - To locate the cells IL-15R } \alpha^{+} \text {was used IF; }\end{array}$ & $\begin{array}{l}\text {-The expression of mRNA IL-15 in mucosal biopsies, and } \\
\text { mRNA sIL-15R } \alpha \text { and IL-15 in serum was not significantly } \\
\text { increased in PCD when compared with HC and not change } \\
\text { with PCD-IFX; } \\
\text { - The expression of IL-15R } \alpha \text { mRNA in mucosal biopsies } \\
\text { was increased in all groups of PCD compared with HC; } \\
\text { - The B-cell lineage was characterized as IL- } 15 \mathrm{R} \alpha^{+} \text {cells. }\end{array}$ \\
\hline$[18]$ & Eder P et al. & 2016 & ES & 17 PCD & $\begin{array}{l}\text { IFX } \\
\text { ADA }\end{array}$ & $\begin{array}{l}\text { - The evaluate of clinical activity and } \\
\text { microscopic activity were used CDAI } \\
\text { and score created by D'Haens et al., } \\
\text { respectively; } \\
\text { - The expression of VEGF and CD } 31^{+} \text {in } \\
\text { biopsies of PCD was realized by IHC. }\end{array}$ & $\begin{array}{l}\text { - A decrease of CDAI, SES-CD, ESR, CRP, D'Haens score } \\
\text { and expression of CD31+ and VEGF after IFX; }\end{array}$ \\
\hline
\end{tabular}




\begin{tabular}{|c|c|c|c|c|c|c|}
\hline [19] & Sena A et al. & 2013 & ES & $\begin{array}{l}28 \mathrm{PCD} \\
12 \mathrm{HC}\end{array}$ & IFX & 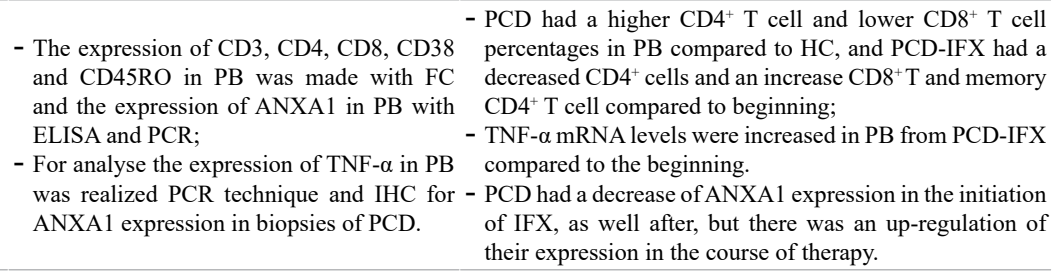 \\
\hline [20] & Eder P et al. & 2013 & ES & 16 PCD & $\begin{array}{l}\text { IFX } \\
\text { ADA }\end{array}$ & $\begin{array}{l}\text { - To evaluate of clinical activity and } \\
\text { microscopic activity CDAI were used; } \\
\text { - Apoptosis-related proteins expression in - In uninflamed areas the expression of apoptosis-related } \\
\text { uninflamed areas of the colon of PCD was proteins did not reveal any change after IFX. } \\
\text { made by IHC. }\end{array}$ \\
\hline [21] & $\begin{array}{l}\text { Moon W } \\
\text { et al. }\end{array}$ & 2015 & ES & 358 PCD & CZP & 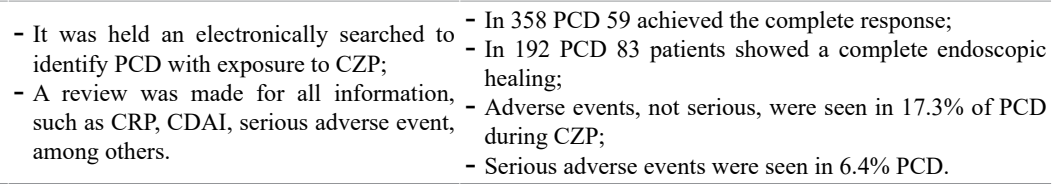 \\
\hline [22] & $\begin{array}{l}\text { Vivio EE } \\
\text { et al. }\end{array}$ & 2016 & ES & 30 PCD & VDZ & $\begin{array}{l}\text { - Laboratory, disease activity and quality-of- - Improvement of quality of life after VDZ; } \\
\text { life were made during therapy in week 14; - Demonstrated a mucosal healing and decrease of CDAI } \\
\text { - During VDZ, mucosal healing and safety } \\
\text { were analysed. } \\
\text { ( } 192 \text { to } 157 \text { ) in week 14; } \\
\text { - Adverse events were seen in } 37 \% \text { in PCD. }\end{array}$ \\
\hline [23] & $\begin{array}{l}\text { Sandborn } \\
\text { et al. }\end{array}$ & 2012 & ES & $526 \mathrm{PCD}$ & USTK & $\begin{array}{l}\text { - The clinical response was higher in PCD than in placebo } \\
\text { in week } 6 \text { and in week } 22 ; \\
\text { - It was evaluated the efficacy and safety } \\
\text { in PCD that were randomly assigned to - Among patients with initial response, } 78.6 \% \text { of PCD with } \\
\text { USTK and } 27.4 \% \text { with placebo were in clinical remission } \\
\text { receive USTK or placebo; } \\
\text { in week } 22 ;\end{array}$ \\
\hline
\end{tabular}

CM: Colonic mucosa; ES: Experimental study; FC: Flow cytometry; IF: Immunofluorescence; IHC: Immunohistochemical; HBI: Harvey Bradshaw Index; NTZ: Natalizumab; PCD: CD patients; PCD-IFX: CD patients under IFX; PCD-NIFX: CD patients not treated with IFX; PDCAI: Pediatric CD activity index; PCR: Quantitative real-time polymerase chain reaction; qRT-PCR: quantitative reverse transcription-polymerase chain reaction; R: Review; REF: Reference; SCK: Secukinuma

\section{Anti-TNF-a therapy \\ Infliximab}

The IFX was approved in 1998. It is an inducing and maintaining remission therapy in $\mathrm{CD}$ patients with the severe, steroid-refractory or fistulising disease by neutralizing TNF- $\alpha$ biological activity. The mechanism of action is not clear but there are evidence points, such as induction of apoptosis of immune cells, neutralization of soluble and transmembrane TNF- $\alpha$, alteration of cytokine secretion and induction of immunoregulatory macrophages. According to current data, the most important pathways induced by this drug are not directly related to TNF- $\alpha$ neutralization as can be observed in Table 1 and 2 [9].

The anti-TNF- $\alpha$ can induce a variety of side effects, such as hypersensitivity to the drug, opportunistic infections, reactivation of tuberculosis, an increased risk of lymphoma and cancer development With the blocking of TNF- $\alpha$, the Th1 cells become inhibited and the IL-23-dependent pathway's stimulation leads to the enhancement of Th17 and overproduction of IL-17A, resulting in skin lesions during IFX treatment. IL-17A is responsible for the development of injury in the dermis [3].

C. Liu et al. demonstrated that Crohn's Disease activity index (CDAI), in 26 patients with active CD, decreased at week 10 after IFX therapy ( $5 \mathrm{mg} / \mathrm{kg}$ at weeks 0,2 and 6) compared with the beginning of treatment (112 \pm 31 vs $213 \pm 34)$. Erythrocyte sedimentation rate (ESR) and C-reactive protein (CRP) levels of serum were also decreased after IFX from $46.8 \pm 6.8 \mathrm{~mm} / \mathrm{h}$ to $23.6 \pm 8.4 \mathrm{~mm} / \mathrm{h}$ and from $52.1 \pm 12.5 \mathrm{mg} / \mathrm{l}$ to $10.3 \pm 4.4 \mathrm{mg} / \mathrm{l}$, respectively [10]. The same response was found in an identical study conducted by Eder P et al. [18] C. Liu et al. showed that almost all $26 \mathrm{CD}$ patients obtained an improved endoscopic score for $\mathrm{CD}$ and only 2 patients showed no response [10]. Eder $\mathrm{P}$ et al. studied the microscopic activity in biopsies after anti-TNF therapy compared to the beginning demonstrated a decrease of a number of mononuclear and polymorphonuclear cells and erosions/ulcers in the mucosal lamina propria and a decrease of D'Haens score (6.33 \pm 3.59 to $5.53 \pm 4.19)$ [18].

Wlodarczyk M. et al. demonstrated that in 18 of 30 adult CD patients developed skin lesions during anti-TNF- $\alpha$ therapy, being that 12 with IFX (66.7\%), $4 \mathrm{ADA}(57.1 \%)$ and $2 \mathrm{CZP}(40 \%)$. The main skin lesions observed were psoriasiform lesions (44.4\%), eczematiforms lesions (22.2\%), erythema (22.2\%), excessive skin dryness (22.2\%), acne $(16.7 \%)$ and furunculosistype lesions (11.1\%). There was an increased level of IL-23 and IL-17A in the serum of all CD patients compared to healthy people and between $\mathrm{CD}$ groups, it was highest in the group with skin lesions [3].

Kim MJ. et al. suggests that both the innate and adaptive immune system play a key role in the pathogenesis of CD [1]. To reach this conclusion, they studied $\mathrm{CD}^{+} \mathrm{CD}^{+} 5^{+} \mathrm{FOXP}^{+}$Treg cells and TIM3 , connected to the adaptive system, and the Human $\beta$-defences (HBD), linked to the innate system. This study showed that the mRNA TIM-3 is highly expressed in the mucosa of CD patients and lower in Peripheral Blood Mononuclear Cells (PBMC) in CD patients compared with HC. This high expression can be explained by the location of activity inflammation, and low levels of TIM-3 on PBMC can be explicated by escape the Th1 cells to Gal-9-induced cell death leading to inflammation. One year after IFX, the expression of the Th1 cell (TIM-3) decreased in colonic mucosa and increased in $\mathrm{PBMC} \mathrm{FOXP}^{+} \mathrm{T}$ regulatory cell (Treg) in PB demonstrated a negative correlation between their frequency and CDAI. There was an increase after TNF- $\alpha$ neutralization duo to the decrease of TNF- $\alpha$ resulting in reduced activation of Treg through TNFR2 and reduction of Tregs apoptosis. Expression of HBD-2 was increased in mucosa of $\mathrm{CD}$ patients compared to $\mathrm{HC}$ and, after IFX, HBD-2 expression was decreased, due to the decreasing inflammatory stimuli. Therefore, both 
Table 2. Differences in the immune system in peripheral blood and intestinal mucosa after administration of infliximab therapy

\begin{tabular}{|c|c|c|c|}
\hline & & Before & After \\
\hline IL-23 & Peripheral blood & + & ++ \\
\hline IL-17A & Peripheral blood & + & ++ \\
\hline IL-17A & Mucosa & + & - \\
\hline IL-17A secretion & Peripheral blood & + & - \\
\hline TIM-3 & Mucosa & + & - \\
\hline TIM-3 & Peripheral blood & - & + \\
\hline HBD-3 & Mucosa & + & - \\
\hline Treg FOXP3 ${ }^{+}$ & Peripheral blood & - & + \\
\hline CD16 $6^{+}$monocyte & Peripheral blood & + & ++ \\
\hline CD16- monocyte & Peripheral blood & - & -- \\
\hline $\mathrm{T} \mathrm{CD}^{+}$ & Peripheral blood & + & - \\
\hline $\mathrm{T} \mathrm{CD}^{+}$ & Peripheral blood & - & + \\
\hline $\mathrm{T}$ memory & Peripheral blood & + & + \\
\hline IL-21 & Mucosa & + & - \\
\hline TNF- $\alpha$ & Mucosa & + & - \\
\hline TNF- $\alpha$ production & Peripheral blood & + & ++ \\
\hline IFN- $\gamma$ & Mucosa & + & - \\
\hline IL-15 & Mucosa & $=$ & $=$ \\
\hline IL-15 & Peripheral blood & $=$ & $=$ \\
\hline IL-15 secretion & Mucosa & + & not available \\
\hline IL-15R $\alpha$ & Peripheral blood & $=$ & $=$ \\
\hline IL- $15 R \alpha$ & Mucosa & + & + \\
\hline ANXA1 & Mucosa & $-/ 0$ & $-/ 0$ \\
\hline CD31 & Mucosa & + & - \\
\hline VEGF & Mucosa & + & - \\
\hline
\end{tabular}

loss of expression.

IS are closely correlated to each other in $\mathrm{CD}$ pathogeneses once there was a negative correlation between TIM-3 in PBMC and HBD-2 in the mucosa [1].

Within the study which analysed the effect of IFX in exacerbated activity of macrophages, N. Nazareth et. al showed that macrophages had an enhances TNF bacterial-stimulation in response to infection for bacteria's in CD patients submitted an IFX therapy compared with $\mathrm{CD}$ patients without IFX and even less in health controls, in isolate mononuclear cells of Peripheral Blood (PB) [9]. It was also evident that $\mathrm{CD} 16^{+}$monocytes were more frequent in the $\mathrm{PB}$ of $\mathrm{CD}$ patients $(6.10 \% \pm 0.71 \%)$ than in $\mathrm{HC}(4.01 \% \pm 0.98 \%)$. These CD16 monocytes increased to $11.22 \% \pm 1.47 \%$ with the addition of IFX in these patients. The CD16 cells decreased along treatment and are more expressed in HC. These results suggest that TNF defective secretion in response to bacterial infection is corrected with IFX. The elevation of CD16+ in CD patients is associated with the elevated inflammatory state of the $\mathrm{CD}$ patients. A possibility of IFX increase these cells are the compensatory response of the host to TNF neutralization [9].

Sena A. et al. presented that $\mathrm{CD}$ patients had higher $\mathrm{CD} 4^{+} \mathrm{T}$ cell percentages and lower levels of $\mathrm{CD}^{+} \mathrm{T}$ cell in $\mathrm{PB}$ compared to $\mathrm{HC}$ [19]. Treatment with IFX decreased $\mathrm{CD}^{+}$cells (from $85 \%$ to $61 \%$ ), increase $\mathrm{CD}^{+} \mathrm{T}$ cells (from $10 \%$ to $29 \%$ ) and increase memory $\mathrm{CD} 4^{+} \mathrm{T}$ cell compared in beginning [19].

As it is unclear what IFX acts to the level of the IS, C. Liu et al. decides to analyse the expression of IL-21, IL-17A, TNF- $\alpha$ and INF- $\gamma$ in the beginning and after 10 weeks of therapy. The mRNA levels of all the cytokines in the intestinal mucosa were increased significantly in CD patients in contrast to HC. The IFX therapy was demonstrated to down-regulate them. The expression of numerous IL- $21^{+}$cells and IL- $17^{+}$cells, by immunostaining, showed the same behaviour that mRNA levels. The results showed that IFX could suppress the differentiation of naive $\mathrm{CD} 4^{+} \mathrm{T}$ cells into Th17. These results were obtained through a study of the PBMC of CD patients with the addition of IFX in culture leading to a reduction of IL-17A secretion. Then, IFX could suppress IL21 expression in mucosa and down-regulate the Th17 cell infiltration, inhibiting the intestinal mucosal inflammation [10].

IL-15 contributed to the pathological inflammation in the bowel but the activity after IFX is unknown. Perrier C. et al. demonstrated that in $65 \mathrm{CD}$ patients, submitted an IFX, the expression of mRNA IL-15 in mucosal biopsies, and mRNA sIL-15Ra and IL-15 in serum was not significantly increased in CD patients when compared with HC and not change with IFX.(17) The expression of IL-15Ra mRNA in mucosal biopsies was increased in CD patients compared with control tissues. In IFX treatment, the expression remained elevated. By immunofluorescence, the B-cell lineage was characterized as IL$15 \mathrm{R} \alpha^{+}$cells. In a different study, they observed an increased secretion of IL-15, in response by LPS or IFN- $\gamma$, by mononuclear cells in the mucosa of CD patients then HC. Therefore, IL-15 seems to contribute to the inflammation in the gut by stimulating $\mathrm{B}$ cells to proliferate and produce antibodies for immune response. IFX therapy does not influence the expression of this cytokine and it's receptor [17].

Sena A. et. al. showed, by confocal microscopic evaluation, that CD patients had a decrease or complete loss of Annexin A1 (ANXA1) protein expression in the initiation of IFX therapy as well after. The lack thereof contributed to the pathogenic mechanisms of IBD. ANXA1 is an antiinflammatory factor that, when enabled, inhibit cell trafficking, cytokine and superoxide radical release and thus inhibits inflammation. There was an upregulation of expression in the course of IFX. Therefore, CD patients can induce an inadequate response to bacterial infection [19].

Induction of apoptosis of immune cells is one of the potential phenomena that can lead to the down-regulation of inflammatory infiltration in the gut tissue. A study from Eder P. et al. showed that IFX caused an increase of apoptosis of mononuclear cells in the lamina propria of inflamed areas. In uninflamed areas, the expression of apoptosis-related proteins did not reveal any change after therapy. The down-regulation of several proinflammatory cytokines, such as IL-6 and IL-12, sensitizes LPMC to pro-apoptotic stimuli. IL-6 can bind to membrane gp130 protein in lymphocytes resulting in a transducer signal, an activator of transcription (STAT) 3, leading to expression of B-cell lymphoma 2 (Bcl-2). IL-12 activates STAT4 inhibiting the activation of caspases. This phenomenon does not affect the uninflamed tissue, once it is down-regulation was only in inflamed areas [20].

The influence of IFX on angiogenesis activity in the gut had been studied by Eder P. et al using immunohistochemistry techniques [18]. The CD31 was highly expressed on endothelial cells in intestinal biopsies taken from inflamed mucosa of $\mathrm{CD}$ patients. The Vascular Endothelial Growth Factor (VEGF) was abundantly expressed in the cells of lamina propria and only focally after treatment. In general, there is a decrease of both after the IFX suggesting that angiogenesis leads to more inflammation by increasing infiltration of poly- and mononuclear cells in inflamed mucosa. The decrease of several proinflammatory and proantigenic mediators after IFX can reduce the vascular proliferation [18].

\section{Certolizumab Pegol}

CZP, a humanised anti-TNF Fab fragment of a monoclonal antibody (Ab), was approved in 2008 for reducing signs and symptoms 
and maintenance of clinical response in moderate-to-severe $\mathrm{CD}$ patients. CZP provided a clinical benefit in patients who had failed IFX and previously responded to IFX, but the response was lost and who could not tolerate IFX. It is a biological therapy that binds to a TNF- $\alpha$ soluble and precursor transmembrane blocking their connection to the receiver TNFR type 1 and type 2, inhibiting the expression of several inflammatory genes. Moon W et al. demonstrated that in $358 \mathrm{CD}$ patients 59 achieved the complete response at a median of 8.7 weeks. The CZP therapy should be used as a first or second line anti-TNF- $\alpha$. Once demonstrated, the use of a third line lead to a low probability of achieving a complete response. In $192 \mathrm{CD}$ patients that performed an ileocolonoscopy after therapy, 83 patients (43.2\%) showed a complete endoscopic healing. There was no case of malignancy or death (see table 1) [21].

\section{Anti-integrin therapy}

Leukocyte infiltration affects the intestinal mucosa by contributing to an environment of proinflammatory cytokines resulting in intestinal inflammation. For infiltration of veins to the intestinal mucosal, the leukocytes decrease the speed through the endothelium "rolling", allowing the leukocytes integrins to interact with their ligands on endothelial cells infiltrating into the mucosa. The integrins $\alpha 4 \beta 1$, $\alpha 4 \beta 7, \alpha E \beta 7$ and $\alpha \mathrm{L} \beta 2$ are the main receivers who contribute to this infiltration [12]. The $\alpha 4 \beta 7$ integrin, expressed in auxiliary and memory $\mathrm{T}$ cells, bind in mucosal vascular addressin cell adhesion molecular 1 (MAdCAM-1) expressed on the endothelial cells, playing an important role in the coupling of the T cells to the membrane [15]. Anti-integrin therapy modulates the inflammation by binding some of these integrins, which has an overall effect of preventing inflammation in the gut through inhibition of leukocyte migration into the mucosa. This biological therapy is one alternative to the TNF- $\alpha$ failure [12].

\section{Natalizumab}

Natalizumab is the first anti-integrin approved for the use in CD patients. This is a monoclonal $\mathrm{Ab}$ directed against the $\alpha 4 \beta 1$ and $\alpha 4 \beta 7$ integrins. The International Efficacy of Natalizumab in CD Response and Remission studied 509 CD patients with moderate to severe diseases submitted randomly to natalizumab and placebo therapy. In patients that received natalizumab and who received placebo the clinical response and clinical remission in week 36 were achieved in $61 \%$ and $44 \%$, and $28 \%$ and $26 \%$ patients, respectively. The problem in this effective treatment was the high probability of 1.4 cases per 1000 patients of developing of progressive multifocal leukoencephalopathy (PML) [12].

\section{Vedolizumab}

The VDZ blocks only the $\alpha 4 \beta 7$ integrins preventing the development of PML once it does not bind to $\alpha 4 \beta 1$. Shelton et al. showed that in week $6,59.5 \%$ of $\mathrm{CD}$ patients that received VDZ achieved clinical response and $35.7 \%$ clinical remission. An adverse event was seen in $10.5 \%$ of patients, five of whom were worsening arthropathy and one a new pyoderma gangrenosum (see table 1) [15].

Vivio E. E. et al. showed that this therapy led to an improvement in clinical disease activity and quality of life for CD patients. The patients that started VDZ demonstrated a significant decrease in CDAI (192 to 157) in week 14 and mucosal healing (see table 1) [22].

VDZ led to a clinical improvement in the majority of IBD patients and was well tolerated, however, the adverse events were higher than expected [15,22].

\section{Ustekinumab (Anti-IL-12 and IL-23)}

Ustekinumab is a human $\operatorname{IgG}_{1 \mathrm{~K}}$ monoclonal $\mathrm{Ab}$ that blocks the p40 subunit express in the receptor of both IL-12 and IL-23. These receptors are expressed in T cells, Natural Killer cells and in antigenpresenting cells. The biological activity of IL-12 and IL-23 is blocked by ustekinumab. In a previous study by Sandborn W. J. et al., the potency in induction phase had effective in moderate-to-severe CD patients, mainly in patients that previously receiving IFX. The clinical response was higher in CD patients that received $6 \mathrm{mg}$ of Ustekinumab, than in placebo in week 6 (39.7\% vs 23.5\%) and in week 22 (69.4\% vs $42.5 \%)$. The clinical remission presented no significant difference between the groups in week 6 . Among patients with a response in the induction phase, $78.6 \%$ of those who received therapy and $27.4 \%$ of receiving placebo were in clinical remission in week 22 (see table 1) [23].

Wils P. et al. observed in 122 patients an elevated CRP levels. After 3 months $65 \%$ (58 of 122) of patients had a clinical benefit while $95 \%$ of patients ( 55 of 58) decreased CRP levels, being that 24 of these normalized values. Endoscopic evaluation was available only in 22 patients. Mucosal healing has been reached in 9\% (2 of 22) and endoscopic response in 77\% (17 of 22) CD patients. An adverse event was developed in 20 patients (16\%), mainly myalgia and infections [14]. In Sandborn W. J. et al. research, a basal-cell carcinoma was reported in one patient but no deaths, serious opportunistic infections reported (see table 1) [23].

Ustekinumab was found to be safe and well tolerated in patients with moderate-to-severe diseases and in patients that failure TNF therapy. These patients demonstrated more chances to have a response to ustekinumab as induction therapy than placebo. The remission phase did not display any significant difference. Those responding to the induction of ustekinumab had increased rates of remission in maintenance therapy with the same drug [23].

\section{Secukinumab (Anti-IL17A)}

Secukinumab is an $\operatorname{IgG}_{\mathrm{k}}$ human monoclonal $\mathrm{Ab}$ that binds to the IL-17A neutralizing their activity. This drug inhibits the production of proinflammatory cytokines, chemokines and inflammatory mediators that cause tissue damage. Secukinumab completed phase I and II trials in psoriasis and rheumatoid arthritis. Balzola F. et al. analysed $59 \mathrm{CD}$ patients who randomly received secukinumab (39 patients) or placebo (29 patients). The reduction of CDAI in the placebo group (-63.1 points) was greater than in the Secukinumab group (-29.2 points). An adverse event was experienced and the secukinumab group underwent a greater adverse event ( $74 \%$ and $28 \%$ ) than in the placebo group $(50 \%$ and $10 \%$ ) (see table 1). Concluding, the Secukinumab was ineffective in this trial. These results suggest that blocking IL-17A may interfere with the protective function in inflammatory CD [13].

\section{Conclusion}

The classical therapies, such as corticosteroids and immunomodulators have shown promising results in CD patients, but there are some patients that continue to suffer from the symptoms previously mentioned due to the insufficient response to these therapies. Recent treatments involving anti-TNF agents were introduced, to improve treatment efficacy in CD patient. These therapies revolutionized the treatment of $\mathrm{CD}$ in the last 15 years improving the quality of life of these patients. A variety of new biologics specific to IBD pathogenesis is now in clinical investigation. These therapies have different mechanisms of action to try to minimize the exacerbated response of IS, that can be observed in synthetic form in Figure 2. Almost all biological therapies are rapid and effective in 

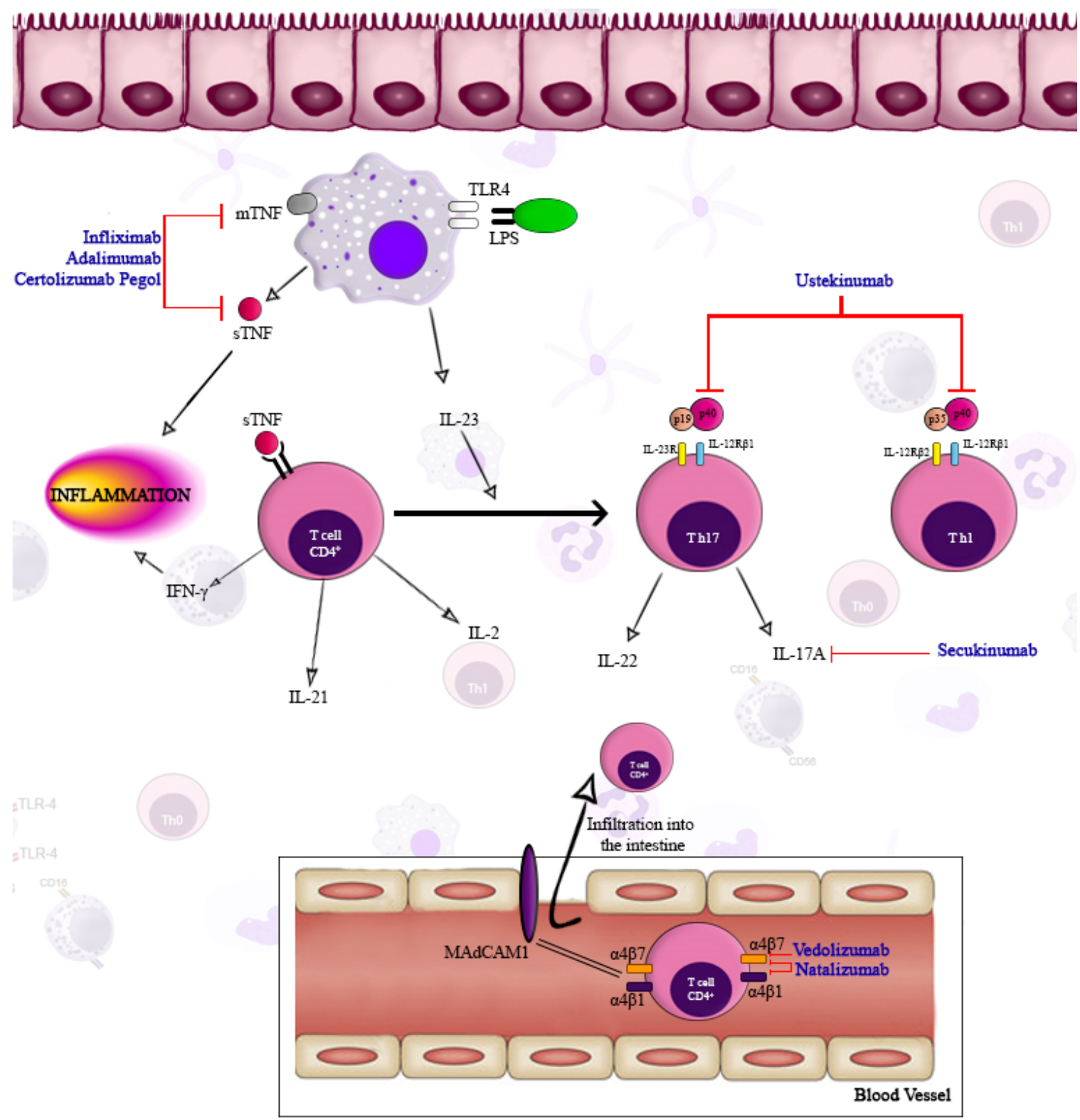

Figure 2. A representative model of mechanisms of action that involves biologic therapies in Crohn's disease. (blue: biologic therapies). Legend: IL-Interleukin; MAdCAM-mucosal vascular addressing cell adhesion molecule; TNF-tumor necrosis factor; TLR-toll like receptor.

clinical response, promote mucosal healing, improved quality of life, reduced need for surgery, among others, but some of them have a high probability to experience severe adverse effects and are expensive. Several types of anti-TNF agents have been developed (ADA, IFX, CZT), anti-integrins (Natalizumab, VDZ) and anti-IL12 and IL-23 agents (Ustekinumab) are now available, but it is necessary to conduct various studies to realize an appropriate method of action for the organism and the efficacy and safety in clinical response and remission.

\section{References}

1. Kim MJ, Lee WY, Choe YH (2015) Expression of TIM-3, Human $\beta$-defensin-2, and FOXP3 and Correlation with Disease Activity in Pediatric Crohn's Disease with Infliximab Therapy Gut liver 9: 370-380. [Crossref]

2. Yarur AJ, Jain A, Sussman DA, Barkin JS, Quintero MA, et al. (2016) The association of tissue anti-TNF drug levels with serological and endoscopic disease activity in inflammatory bowel disease: the ATLAS study. Gut 65: 249-255. [Crossref]
3. Wlodarczyk M, Sobolewska A, Wójcik B, Loga K, Fichna J, et al. (2014) Correlations between skin lesions induced by anti-tumor necrosis factor-a and selected cytokines in Crohn's disease patients. World J Gastroenterol 20: 7019-7026. [Crossref]

4. Cheon JH (2017) Understanding the complications of anti-tumor necrosis factor therapy in East Asian patients with inflammatory bowel disease. $J$ Gastroenterol Hepatol 32: 769-777. [Crossref]

5. Billmeier U, Dieterich W, Neurath MF, Atreya R (2016) Molecular mechanism of action of anti-tumor necrosis factor antibodies in inflammatory bowel diseases. World $J$ Gastroenterol 22: 9300-9313. [Crossref]

6. Brown M, Hughes KR (2014) Toll-like receptor expression in crypt epithelial cells putative stem cells and intestinal myofibroblasts isolated from controls and patients with inflammatory bowel disease. Clin Exp Immunol 8: 28-39. [Crossref]

7. Nakaira-Takahagi E, Golim MA, Bannwart CF, Puccia R, Peraçoli MT (2011) The glicoprotein (gp43) of Paracoccidioides brasiliensis modulates TLR2 and TLR4 expression and cytokine production by human monocytes. Med Mycol 49: 694-703. [Crossref]

8. Cario E (2010) Toll-like receptors in inflammatory bowel diseases: a decade later. Inflamm Bowel Dis 16: 1583-1597. [Crossref] 
9. Nazareth N, Magro F, Silva J, Duro M, Gracio D, Coelho R, et al. (2014) Infliximab therapy increases the frequency of circulating CD16+ monocytes and modifies macrophage cytokine response to bacterial infection. Clin Exp Immunol 177: 703-711. [Crossref]

10. Liu C, Xia X, Wu W, Wu R, Tang M, Chen T, et al. (2013) Anti-tumour necrosis factor therapy enhances mucosal healing through down-regulation of interleukin-21 expression and T helper type 17 cell infiltration in Crohn's disease. Clin Exp Immunol 173: 102-111. [Crossref]

11. Cote-Daigneault J, Bouin M, Lahaie R, Colombel J-FF, Poitras P, Cote-Daigneault J, et al. (2015) Biologics in inflammatory bowel disease: what are the data? United Eur Gastroenterol J 3: 419-428. [Crossref]

12. McLean LP, Cross RK (2016) Integrin Antagonists as Potential Therapeutic Options for the Treatment of Crohn's Disease. Expert Opin Investig Drugs 25: 263-273. [Crossref]

13. Balzola F, Cullen G, Ho GT, Russell RK, Wehkamp J (2012) Secukinumab, a human anti-IL-17A monoclonal antibody, for moderate to severe Crohn's disease: Unexpected results of a randomised, double-blind placebo-controlled trial. Inflamm Bowel Dis Monit 13: 27-28. [Crossref]

14. Wils P, Bouhnik Y, Michetti P, Flourie B, Brixi H, et al. (2016) Subcutaneous Ustekinumab Provides Clinical Benefit for Two-Thirds of Patients with Crohn's Disease Refractory to Anti-Tumor Necrosis Factor Agents. Clin Gastroenterol 14: 242250. [Crossref]

15. Shelton E, Allegretti JR, Stevens B, Lucci M, Khalili H, Nguyen DD, et al. (2015) Efficacy of Vedolizumab as Induction Therapy in Refractory IBD Patients. Inflamm Bowel Dis 21: 2879-2885. [Crossref]

16. Dai C, Liu W-X, Jiang M, Sun M-J. (2014) Mucosal healing did not predict sustained clinical remission in patients with IBD after discontinuation of one-year infliximab therapy. PLoS One 9(10): e110797. [Crossref]
17. Perrier C, Arijs I, Staelens D, Breynaert C, Cleynen I, Covens K, et al. (2013) Interleukin-15 receptor??? expression in inflammatory bowel disease patients before and after normalization of inflammation with infliximab. Immunology 138: 47-56. [Crossref]

18. Eder P, Lykowska-Szuber L, Iwanik K, Krela-Kazmierczak I, Stawczyk-Eder K, Majewski P, et al. (2016) The influence of anti-TNF therapy on CD31 and VEGF expression in colonic mucosa of crohn???s disease patients in relation to mucosal healing. Folia Histochem Cytobiol [Internet]. 54: 75-80. [Crossref]

19. Sena A, Grishina I, Thai A, Goulart L, Macal M, Fenton A, et al. (2013) Dysregulation of Anti-Inflammatory Annexin A1 Expression in Progressive Crohns Disease. PLoS One 8(10): e76969. [Crossref]

20. Eder P, Lykowska-Szuber L, Krela-Kazmierczak I, Stawczyk-Eder K, Sterzynska $\mathrm{K}$, et al. (2013) Anti-TNF antibodies do not induce the apoptosis of lamina propria mononuclear cells in uninflamed intestinal tissue in patients with Crohn's disease. Folia Histochem Cytobiol 51: 239-243. [Crossref]

21. Moon W, Pestana L, Becker B, Loftus E V, Hanson KA, Bruining DH, et al. (2015) Efficacy and safety of certolizumab pegol for Crohn's disease in clinical practice. Aliment Pharmacol Ther 42: 428-440. [Crossref]

22. Vivio EE, Kanuri N, Gilbertsen JJ, Monroe K, Dey N, et al. (2016) Vedolizumab Effectiveness and Safety Over the First Year of Use in an IBD Clinical Practice. $J$ Crohns Colitis 10: 402-409. [Crossref]

23. Sandborn WJ, Gasink C, Gao LL, Blank MA, Johanns J, et al. (2012) Ustekinumab induction and maintenance therapy in refractory Crohn's disease. $N$ Engl J Med. 367 : 1519-1528. [Crossref]

Copyright: C2017 Serra D. This is an open-access article distributed under the terms of the Creative Commons Attribution License, which permits unrestricted use, distribution, and reproduction in any medium, provided the original author and source are credited. 